\title{
Kepraktisan Bahan Ajar Statistika Pendidikan Fisika Bermuatan Model Cooperative Problem Solving
}

\author{
Renol Afrizon, Wahyuni Satria Dewi \\ Jurusan Fisika, FMIPA, Universitas Negeri Padang \\ Email: afrizon@fmipa.unp.ac.id ${ }^{1)}$,wahyunisatria@fmipa.unp.ac.id ${ }^{1)}$
}

\begin{abstract}
The statistics of physics education are compulsory course with a lot of material descriptions so the lectures must be assisted by the use of teaching materials. The lectures of statistics of physics education that took place in the July-December 2017 semester illustrates that: 1) teaching materials are less attractive to students, 2) the assignments given are quite clear and sufficient in accordance with the level of thinking of students, 3) materials delivered by the lecturer is in accordance with the targets in the syllabus with some material is still abstract, 4) the lecture have been pursued in accordance with the syllabus but the methods used have not varied and 5) students learn material of statistic of physics education only from the lecturer explanation so that only a few students can answer statistical problems quickly and correctly. This indicates that it is need provided teaching materials with a cooperative problem solving model. The author has tried to design teaching materials of statistic of physics education with cooperative problem solving models with very valid criteria according to the assessment of six experts with educational qualifications of statistics and physics education. However, this teaching material has not been tested at normal conditions in the lectures so that the level of practicality has not been revealed. The aim of this study was to determine the practicality level of educational statistical teaching materials containing cooperative problem solving models according to users, namely lecturers and students who listed in the course. Type of research is research and devel-opment with the ADDIE model. The ADDIE model stands for Analyze, Design, Develop, Implement and Evaluation. This research is part of the Implementation stage where development products are implemented in real terms so that the level of practicality can be measured with indicators of ease of use, attractiveness and efficiency. Data collection used student response questionnaires and lecturer response questionnaires with a Likert scale. Data analysis used descriptive statistic analysis techniques. The results showed that teaching materials of physics education statistics had very practical criteria (lecturers opinion) and practical (students opinion). The conclusion of this study is the teaching materials of statistic of physics education with cooperative problem solving model has been practically used in lectures.
\end{abstract}

Keywords : Practicallity, Teaching Materials, Cooperative Problem Solving

This an open access article distributed under the Creative Commons 4.0 Attribution License, which permits unrestricted use, distribution, and reproduction in any medium, provided the original work is properly cited. $\odot 2018$ by author and Universitas Negeri $P$ adang.

\section{PENDAHULUAN}

Statistika Pendidikan Fisika merupakan matakuliah wajib yang harus diikuti oleh mahasiswa program studi pendidikan fisika Fakultas Matematika dan Ilmu Pengetahuan Alam (FMIPA) pada semester pertama. Mata kuliah ini menjadi matakuliah prasyarat bagi mahasiswa sebelum mengambil mata kuliah bidang pendidikan fisika, seperti Evaluasi Pembelajaran Fisika dan Metodologi Penelitian dan Publikasi. Capaian pembelajaran dari matakuliah ini adalah mahasiswa mampu mengkaji materi statistika deskriptif dan statistika inferensial, menyelesaikan masalah terkait pengambilan kesimpulan/keputusan tentang hasil penelitian pendidikan secara statistik, dan mendeskripsikannya dengan baik dan benar.

Statistika Pendidikan Fisika memiliki bobot 3 SKS dengan materi perkuliahan dalam meliputi konsep-konsep dasar statistika pendidikan, statistika deskriptif dan statistika inferensial. Statistika deskriptif mencakup ukuran pusat, ukuran letak dan ukuran simpangan, distribusi frekuensi, peluang, dan distribusi variabel random. Sedangkan, kajian statistika inferensialmencakup estimasi parameter, uji hipotesis, analisis variansi, regresi linier sederhana dan korelasi liniersederhana. Agar perkuliahan statistika pendidikan fisika dapat berjalan sesuai dengan Rencana Pembelajaran Semester (RPS), maka 
harus dibantu dengan bahan ajar. Bahan ajar yang digunakan harus dirancang berdasarkan kebutuhan. Hasil analisis kebutuhan bahan ajarterlihat jelas pada Tabel 1 .

Tabel 1. Hasil Analisis Kebutuhan

\begin{tabular}{|c|c|c|}
\hline No & Jenis & Hasil Analisis \\
\hline 1. & $\begin{array}{l}\text { Analisis } \\
\text { Bahan Ajar }\end{array}$ & $\begin{array}{l}\text { Bahan ajar statistika } \\
\text { sudah banyak dibuat } \\
\text { tetapi belum sepenuhnya } \\
\text { menarik untuk dipelajari } \\
\text { secara mandiri }\end{array}$ \\
\hline 2. & $\begin{array}{l}\text { Analisis } \\
\text { tugas }\end{array}$ & $\begin{array}{l}\text { Tugas yang diberikan } \\
\text { cukup jelas dan cukup } \\
\text { sesuai dengan tingkat } \\
\text { berpikir mahasiswa }\end{array}$ \\
\hline 3. & $\begin{array}{l}\text { Analisis } \\
\text { Materi } \\
\text { Perkuliahan }\end{array}$ & 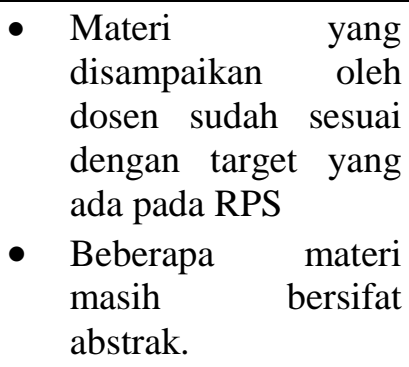 \\
\hline 4. & $\begin{array}{l}\text { Analisis } \\
\text { Pelaksanaan } \\
\text { Perkuliahan }\end{array}$ & $\begin{array}{lr}\text { Perkuliahan } & \text { sudah } \\
\text { diupayakan } & \text { sesuai } \\
\text { dengan RPS tetapi } \\
\text { metode yang digunakan } \\
\text { belum bervariasi }\end{array}$ \\
\hline 5. & $\begin{array}{l}\text { Analisis } \\
\text { karateristik } \\
\text { mahasiswa }\end{array}$ & $\begin{array}{l}\text { Mahasiswa mempelajari } \\
\text { materi Statistika Pendidi } \\
\text { kan Fisika hanya dari } \\
\text { penjelasan dosen sehing } \\
\text { ga hanya sebagian } \\
\text { mahasiswa dapat } \\
\text { menjawab persoalan } \\
\text { statistik dengan cepat dan } \\
\text { benar. }\end{array}$ \\
\hline
\end{tabular}

(Sumber: Dewi, 2018: 97-99)

Hasil analisis kebutuhan pada Tabel 1 dijadikan sebagai dasar dalam penyusunan bahan ajar Statistika Pendidikan Fisika. Hasil analisis karakteristik mahasiswa memberikan kontribusi pada bahan ajar yang dirancang harus memuat tugas terstruktur sehingga mahasiswa bisa mempelajari materi secara mandiri.Hasil analisis tugas memberikan kontribusi langsung pada bahan kajian dan tugas terstruktur. Hasil analisis materi perkuliahan juga dijadikan pertimbangan dalam merancang pengantar materi, bahan kajian dan tugas terstruktur dengan menyajikan permasalahan yang nyata. Selain itu, hasil analisis terhadap bahan ajar memberi kontribusi pada desain bahan ajar yang dibuat sehingga memiliki perpaduan warna seperti terlihat pada Gambar 1.
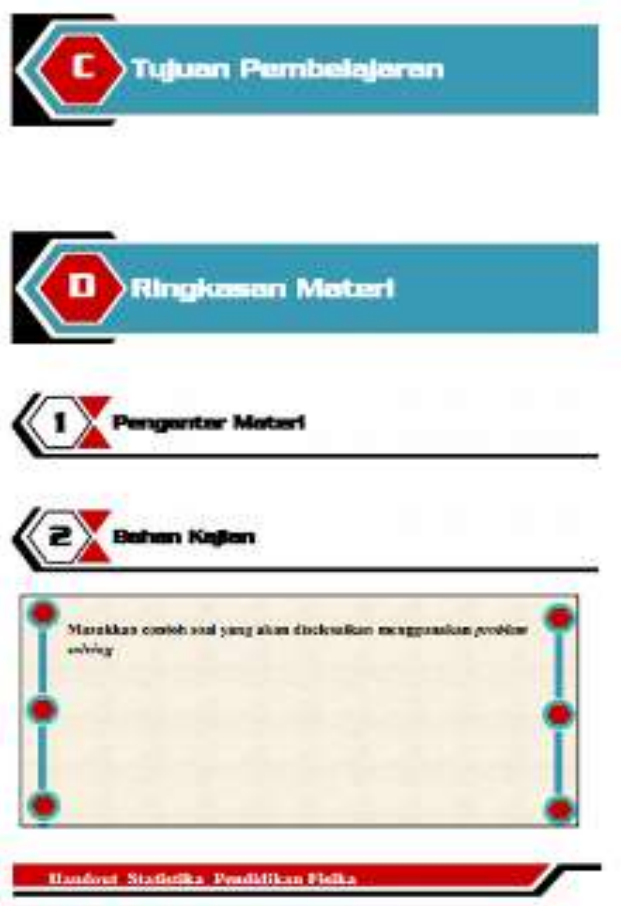

Gambar 1. Bagian dari Template Bahan Ajar

Bahan kajian pada Gambar 1 menerapkan sebuah model pembelajaran yang sesuai dengan kebutuhan civitas akademika pendidikan fisika yang terungkap dari hasil analisis terhadap pelaksanaan perkuliahan. Model pembelajaran yang digunakan dalam pengembangan bahan ajar adalah model cooperative problem solving. Langkah-langkah yang digunakan dalam mengembangkan bahan ajar adalah dengan mengadopsi lima langkah model cooperative problem solvingdalam framework fisika yang dikembangkan oleh Heller $(2010,184)$. Adapun sintaks dari model cooperative problem solving yang digunakan adalah: 1) Recognize the problem (fokus pada visualisasi masalah), 2) Describe the problem in terms of the field (uraian permasalahan secara konsep statistik), 3) Plan a solution (merencanakan solusi penyelesaian permasalahan), 4) Execute the plan (melaksanakan rencana penyelesaian masalah), 5) Evaluate the solution (mengecek dan mengevaluasi apakah mahasiswa bisa menjawab pertanyaan dengan langkah yang sesuai, apakah proses berfikir mahasiswa masuk 
akal, dan apakah jawaban mahasiswa sudah lengkap).

Bahan ajar statistika pendidikan fisika bermuatan model cooperative problem solving telah diuji kelayakannya oleh 6 orang pakar yang berasal dari latar belakang statistik dan pendidikan fisika. Secara keseluruhan bahan ajar statistika pendidikan fisika ini sudah sangat valid dimana aspek kelayakan isi dengan nilai rata-rata 83,03, aspek kelayakan penyajian didapatkan 88,64, aspek kelayakan kebahasaan dengan nilai rata-rata 81,25 , dan aspek kelayakan kegrafikaan didapat nilai rata-rata 87,50. Meskipun demikian, bahan ajar ini belum diujicobakan secara nyata di dalam perkuliahan sehingga tingkat kepraktisannyabelum terungkap.

Praktikalitas berkaitan dengan keterpakaian bahan perkuliahan oleh pengguna yaitu mahasiswa dan dosen serta ahli lainnya. Indikator kepraktisan diperoleh berdasarkan defenisi dan pertimbangan dari Kamus Besar Bahasa Indonesia (KBBI) dan beberapa ahli. Kamus Besar Bahasa Indonesia (KBBI) mendefenisikan kepraktisan, diantaranya: 1) berdasarkan praktik, 2) mudah dan senang memakainya, dan 3) efisien. Jan (2013:66) menyatakan bahwa praktikalitas harus mempertimbangkan indikator kejelasan, berguna, dan hemat biaya. Selain itu, Fauzan (2002) mengungkapkan bahwa dalam menguji kepraktisan sebuah bahan ajar harus mempertimbangkan apakah produk menarik dan dapat digunakan. Berdasarkan defenisi dan pendapat ahli maka indikator kepraktisan yang digunakan adalah kemudahan penggunaan, daya tarik dan efisiensi.

Kepraktisan sebuah bahan ajar diujicobakan pada kelas dengan kondisi nomal. Hal ini sejalan dengan pendapat Ahmad Fauzan (2002) dan Jan (2013:66) mengemukakan bahwa "praktikalitas berguna untuk melihat sejauh mana pemanfaatan produk oleh pengguna (dosen dan mahasiswa pada kondisi normal". Kondisi normal disini maksudnya jika materi uji hipotesis direncanakan pada pertemuan 10 dan 11 di dalam rencana perkuliahan semester maka harus dilaksanakan sesuai rencana. Selain itu, mahasiswa dan dosen yang menjadi kelas uji coba belum melaksanakan perkuliahan terkait materi tersebut. Oleh karena itu, kegiatan penelitian yang bertujuan menentukan tingkat kepraktisan bahan ajar statistika pendidikan bermuatan model cooperative problem solving menurut pengguna yaitu dosen pengampu dan mahasiswa yang sedang mengikuti perkuliahan.

\section{METODE PENELITIAN}

Penelitian ini merupakan penelitian dan pengembangan (research and the development) denganmodel ADDIE. Model ADDIE berasal singkatan dari Analyze, Design, Develop or, Implement and Evaluation (Khoe: 2016). Skema model ini dapat dilihat pada Gambar 2.

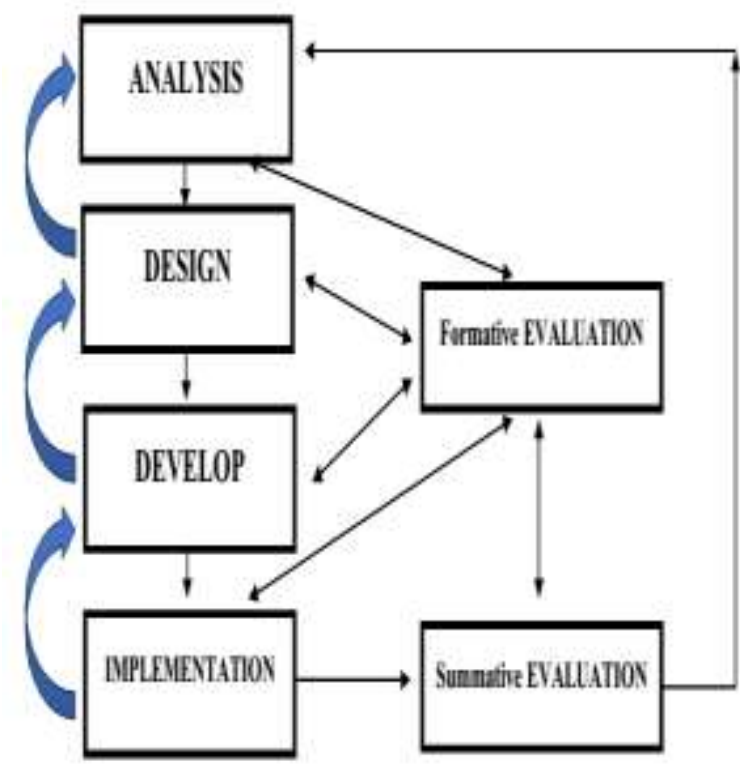

Gambar 2. Model ADDIE dan Tahapannya (Sumber: Khoe, 2016:68)

Penelitian ini merupakan salah satu bagian dari tahap Implementation. Pada tahap ini produk pengembangan diimplementasikan secara riil sehingga dapat dilihat tingkat kepraktisannya. Bahan ajar yang dikembangkan harus dilihat kualitasnya dalam pembelajaran dari segi kemenarikan dan efisiensinyadalam pembelajaran (Tegeh, 2014: 43). Kemenarikan dan efisiensi pembelajaran berkaitan erat dengan indikator kepraktisan. Kemenarikan berkaitan dengankemampuan produk pengembangan sebagai panduan dalam menciptakan suasana belajar yang menyenangkan, menantang dan memotivasi belajar mahasiswa. Efisiensi pembelajaran berkaitan dengan penggunaan dan pemanfaatan segala sumber daya secara efisien dalam pembelajaran.

Penelitian ini diujicobakan kepada dosen dan mahasiswa angkatan 2018 yang telah terdaftar pada mata kuliah Statistika Pendidikan 
Fisika Semester Juli-Desember 2018. Instrumen uji praktikalitas yang digunakan terdiri dari lembar praktikalitas berdasarkan angket respon mahasiswa dan angket respon dosen dengan menggunakan skala Likert. Angket respon mahasiswa digunakan untuk mendapatkan respon mahasiswa terhadap kepraktisan bahan ajar yang dikembangkan. Angket ini diisi oleh mahasiswa setelah mengikuti proses perkuliahan. Sementara itu, angket respon dosen digunakan untuk melihat respon dosen terhadap kepraktisan bahan ajar yang dikembangkan. Instrumen ini diisi oleh dosen setelah proses perkuliahan selesai.

Teknik analisis data yang digunakan adalah analisis statistik deskriptif. Adapun tingkat kepraktisan mengacu pada kriteria berikut ini. 1) tidak praktis $(0 \%$ - 20\%), 2) kurang praktis $(21 \%-40 \%), 3)$ cukup praktis $(41 \%-60 \%), 4)$ praktis $(61 \%-80 \%)$, dan 5) sangat praktis $(81 \%$ - 100\%) (dimodifikasi dari Riduwan, 2009:89).

\section{HASIL DAN PEMBAHASAN}

\section{Hasil Penelitian}

Uji praktikalitas berfungsi untuk mengetahui tingkat kepraktisan penggunaan bahan ajar statistika pendidikan fisika bermuatan model cooperative problem solving yang dikembangkan. Uji praktikalitas dilakukan terhadap 2 orang dosen pengampu matakuliah statistika pendidikan fisika dan dua kelompok mahasiswa yang sedang mengikuti perkuliahan statistika pendidikan fisika berjumlah 56 orang.

\section{a. Praktikalitas Bahan Ajar oleh Dosen}

Berdasarkan hasil analisis angket uji praktikalitas oleh dosen pengampu mata kuliah statistika pendidikan fisika, diperoleh tingkat kepraktisan bahan ajar bermuatan model cooperative problem solving berada pada kriteria sangat praktis dengan $83,19 \%$. Nilai ini diperoleh dari rata-rata nilai ketiga indikator kepraktisan. Indikator pertama yaitu kemudahan penggunaan bahan ajar dengan nilai 81,25\%. Indikator kedua yaitu daya tarik bahan ajar memiliki persentase tertinggi dengan nilai $85 \%$. Indikator ketiga yaitu efisiensi penggunaan bahan ajar pada proses perkuliahan memperoleh nilai sebesar $83,33 \%$. Nilai kepraktisan tersebut juga dapat disajikan pada Gambar 3 berikut ini.

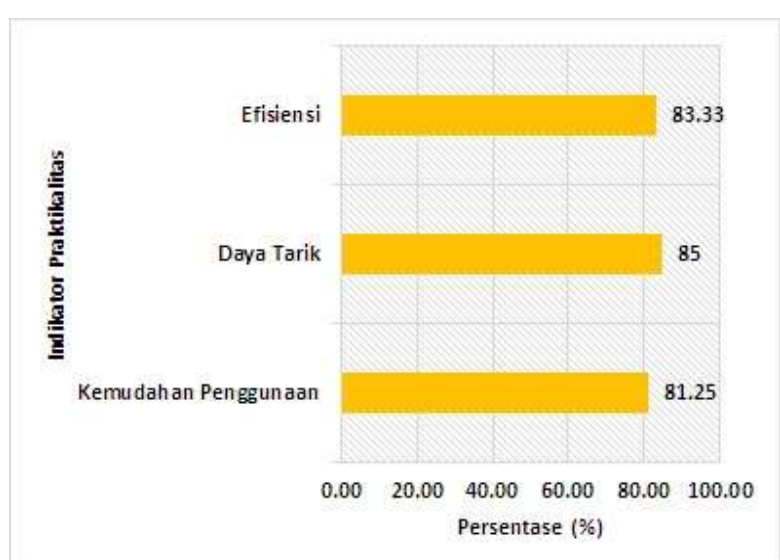

Gambar 3. Hasil Uji Praktikalitas oleh Dosen

Rincian nilai dari setiap indikator praktikalitas dapat diuraikan berikut ini.

\section{1) Kemudahan penggunaan bahan ajar}

Indikator kemudahan penggunaan terdiri dari enam item yaitu: 1) tujuan pembelajaran pada bahan ajar memudahkan dosen memahami garisgaris besar materi perkuliahan, 2) materi yang disajikan pada bahan ajar mudah dipahami, 3) materi yang disajikan pada bahan ajar sistematis, 4) penyajian materi dalam bahan ajar ini memudahkan dosen menuntun mahasiswa dalam memahami rumus-rumus dan simbol statistik dengan benar, 5) penyajian materi dalam bahan ajar ini memudahkan dosen menuntun mahasiswa dalam membuat grafik dengan benar, dan 6) tugas terstruktur dalam bahan ajar membantu dosen mengevaluasi pengetahuan mahasiswa yang diperoleh selama perkuliahan. Nilai indikator ini dapat dilihat pada Gambar4.

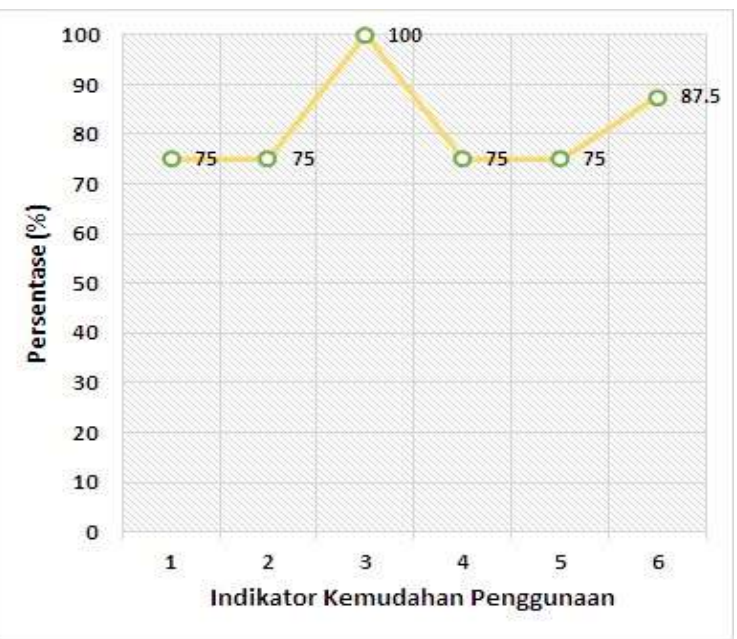

Gambar 4. Indikator Kemudahan Penggunaan

Gambar 4 menunjukkan bahwa nilai maksimum yaitu $100 \%$ pada butir 3, artinya 
bahan ajar yang dikembangkan sudah sistematis. Selain itu, tugas terstruktur yang ada pada bahan ajar sudah bisa menilai sejauh mana pemahaman mahasiswa selama mengikuti pembelajaran. Capaian nilai dari butir ini sebesar $87,5 \%$.

\section{2) Daya tarik bahan ajar}

Indikator daya tarik bahan ajar terdiri dari limaitem yaitu: 1) bahan ajar memiliki tampilan yang menarik, 2) komposisi gambar dan warna dalam bahan ajar menarik untuk dibaca, 3) penyajian materi pada bahan ajar dapat mengaktifkan mahasiswa untuk bertanya, 4) penyajian materi pada bahan ajar dapat merangsang ide atau gagasan mahasiswa dalam memecahkan masalah yang diberikan, 5) penyajian materi yang ada dalam bahan ajar statistika pendidikan fisika dapat mengembangkan keterampilan pemecahan masalah mahasiswa. Nilai daya tarik bahan ajar dapat dilihat jelas pada Gambar 5.

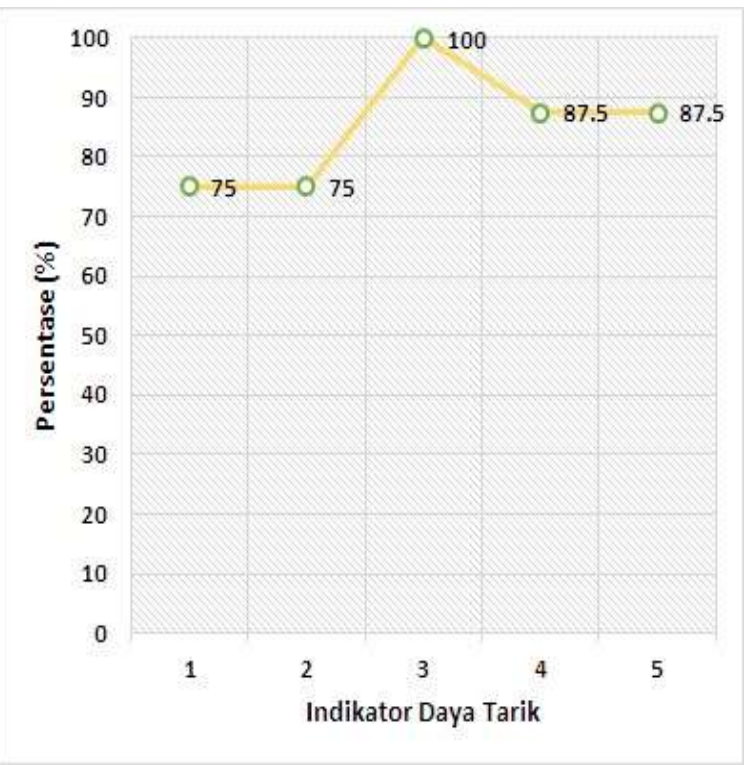

Gambar 5. Indikator Daya Tarik Bahan ajar

Dari Gambar 5, indikator daya tarik bahan ajar yang sudah dikembangkan ini dapat dijelaskan bahwa penyajian materi sudah dapat mengaktifkan seluruh mahasiswa untuk bertanya dengan nilai $100 \%$. Daya tarik bahan ajar juga dinilai sangat bagus pada butir penyajian materi sudah dapat mengembangkan keterampilan pemecahan masalah, merangsang ide mahasiswa dalam memecahkan masalah dengan nilai $87,5 \%$. Daya tarik bahan ajar juga dinilai sangat menarik dari segi komposisi gambar dan warna serta tampilan bahan ajar.

\section{3) Efisiensi bahan ajar}

Indikator efisiensi bahan ajar terdiri dari tiga item yaitu: 1) penggunaan bahan ajar dapat membuat mahasiswa cermat dalam menyelesaikan permasalahan, 2) penggunaan bahan ajar dapat menyesuaikan waktu perkuliahan statistika pendidikan fisika di kelas dengan yang ada pada silabus, 3) bahan ajar dapat digunakan oleh dosen untuk melatih kemandirian mahasiswa untuk belajar. Nilai efisiensi bahan ajar dapat dilihat jelas pada Gambar 6.

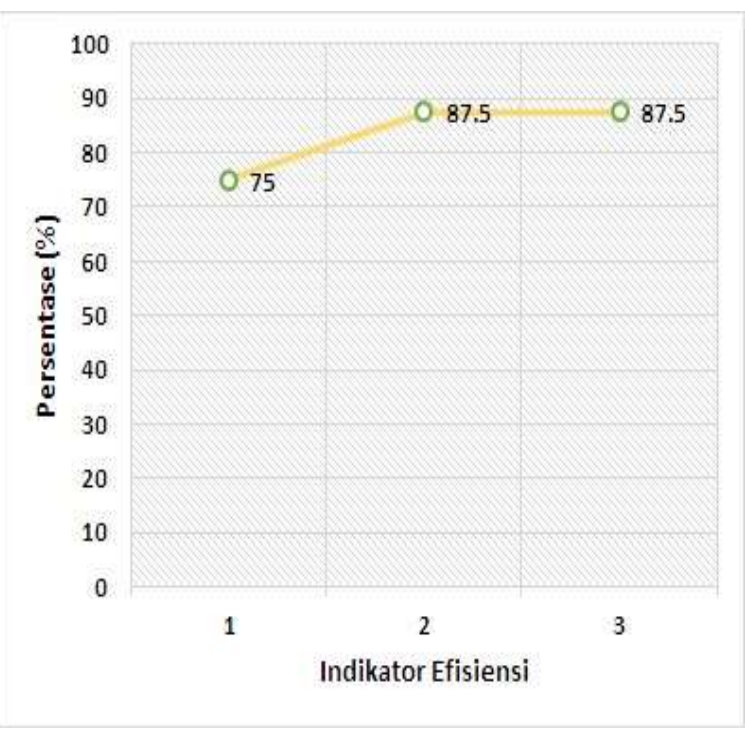

Gambar 6. Indikator Efisiensi Penggunaan Bahan ajar

Gambar 6 memperlihatkan bahwa indikator efisiensi penggunaan bahan ajar dapat dijabarkan bahwa bahan ajar yang sudah dikembangkan dapat digunakan untuk melatih kemandirian mahasiswa untuk belajar, ini juga didukung dengan adanya tersedia tugas terstruktur pada bahan ajar. Penilaian terhadap butir ini mencapai nilai 87,5. Penggunaan bahan ajar ini juga sudah dapat mengefisienkan waktu perkuliahan dengan baik sesuai perencanaan pada silabus. Penilaian terhadap butir ini juga mencapai nilai 87,5. Selain itu penggunaaan bahan ajar juga dapat melatih kecermatan mahasiswa dalam menyelesaikan persoalan statistika. Penilaian terhadap butir ini mencapai nilai 75 . 


\section{b. Hasil Praktikalitas Bahan Ajar oleh Mahasiswa}

Berdasarkan hasil analisis angket uji praktikalitas yang diberikan oleh dosen mahasiswa yang telah menggunakan bahan ajar, diperoleh hasil kepraktisan bahan ajar statistika pendidikan Fisika menggunakan model cooperative problem solving berada pada kriteria praktis dengan nilai rata-rata sebesar $75,71 \%$. Nilai ini diperoleh dari rata-rata nilai tiga indikator kepraktisan. Aspek pertama yaitu kemudahan penggunaan bahan ajar dengan nilai rata-rata $76,55 \%$. Aspek kedua yaitu daya tarik bahan ajar dengan nilai rata-rata 71,50\%. Aspek efisiensi penggunaan bahan ajar pada proses perkuliahan memperoleh nilai rata-rata sebesar $79,09 \%$. Hasil nilai setiap aspek dapat dilihat pada Gambar 7.

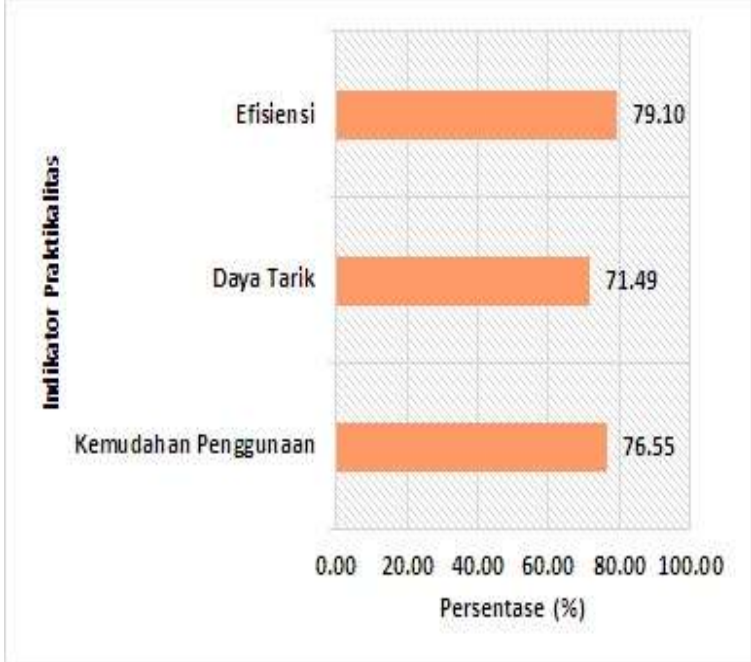

Gambar 7. Hasil Praktikalitas oleh Mahasiswa

Rincian nilai dari setiap indikator praktikalitas dapat diuraikan berikut ini.

1) Kemudahan penggunaan bahan ajar

Indikator kemudahan penggunaan terdiri dari enam item yaitu: 1) tujuan pembelajaran pada bahan ajar memudahkan mahasiswa memahami garis-garis besar materi perkuliahan, 2) materi yang disajikan pada bahan ajar mudah dipahami, 3) materi yang disajikan pada bahan ajar sistematis, 4) penyajian materi dalam bahan ajar ini memudahkan mahasiswa dalam memahami rumus-rumus dan simbol statistik dengan benar, 5) penyajian materi dalam bahan ajar ini memudahkan mahasiswa dalam membuat grafik dengan benar, dan 6) tugas terstruktur dalam bahan ajar membantu mahasiswa mengevaluasi pengetahuan yang diperoleh selama perkuliahan. Nilai indikator ini dapat dilihat pada Gambar 8.

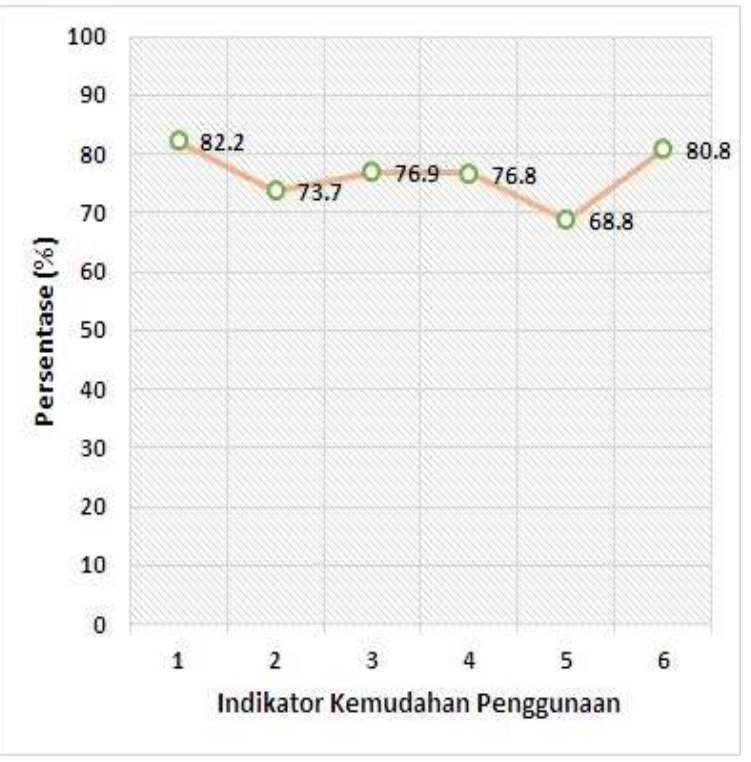

Gambar 8. Indikator Kemudahan Penggunaan

Gambar 8 menjelaskan bahwa nilai tertinggi dari indikator kemudahan penggunaan yaitu $82,2 \%$ yang menyatakan bahwa tujuan pembelajaran telah memudahkan mahasiswa memahami garis-garis besar materi perkuliahan. Tugas terstruktur yang ada pada bahan ajar sudah bisa menilai sejauh mana pemahaman mahasiswa selama mengikuti pembelajaran. Capaian nilai dari butir ini sebesar $80,8 \%$. Namun penyajian materi dalam bahan ajar belum cukup bisa memudahkan mahasiswa untuk membuat grafik dengan benar. Hal ini terlihat dari nilai yang dicapai pada butir ini hanya $68,8 \%$.

\section{2) Daya tarik bahan ajar}

Indikator daya tarik bahan ajar memiliki lima item, yaitu: 1) bahan ajar memiliki tampilan yang menarik, 2) komposisi gambar dan warna dalam bahan ajar menarik untuk dibaca, 3) penyajian materi pada bahan ajar dapat mengaktifkan mahasiswa untuk bertanya, 4) penyajian materi pada bahan ajar dapat merangsang ide atau gagasan mahasiswa dalam memecahkan masalah yang diberikan, 5) penyajian materi yang ada dalam bahan ajar statistika pendidikan fisika dapat mengembangkan keterampilan pemecahan masalah mahasiswa. Nilai daya tarik bahan ajar dapat dilihat jelas pada Gambar 9. 


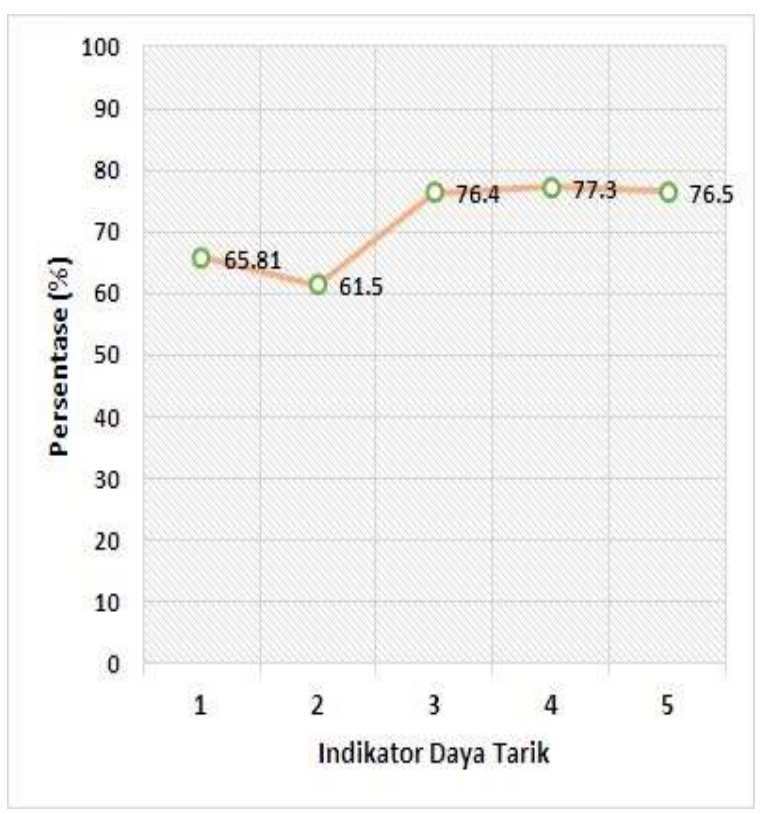

Gambar 9. Indikator Daya Tarik Bahan Ajar

Dari Gambar 9, terlihat bahwa butir keempat dan kelima yang berkaitan dengan komposisi gambar dan warna serta tampilan bahan ajar masih dinilai cukup menarik bagi mahasiswa dengan perolehan nilai hanya $61,5 \%$ dan $65,81 \%$. Penyajian materi pada bahan ajar dapat merangsang ide mahasiswa dalam memecahkan masalah dengan nilai $77,3 \%$, diikuti oleh butir penyajian materi sudah dapat mengembangkan keterampilan pemecahan masalah dengan pencapaian nilai yaitu $76,5 \%$. Penyajian materi sudah dapat mengaktifkan mahasiswa untuk bertanya memperoleh nilai $76,4 \%$.

\section{3) Efisiensi penggunaan bahan ajar}

Indikator efisiensi bahan ajar terdiri dari tiga item yaitu: 1) penggunaan bahan ajar dapat membuat mahasiswa cermat dalam menye lesaikan permasalahan, 2) penggunaan bahan ajar dapat menyesuaikan waktu perkuliahan statistika pendidikan fisika di kelas dengan yang ada pada silabus, 3)bahan ajar dapat digunakan secara mandiri sewaktu-waktu meskipun tidak ada dosen. Nilai efisiensi bahan ajar saat digunakan oleh mahasiswa dalam perkuliahan dapat dilihat jelas pada Gambar 10.

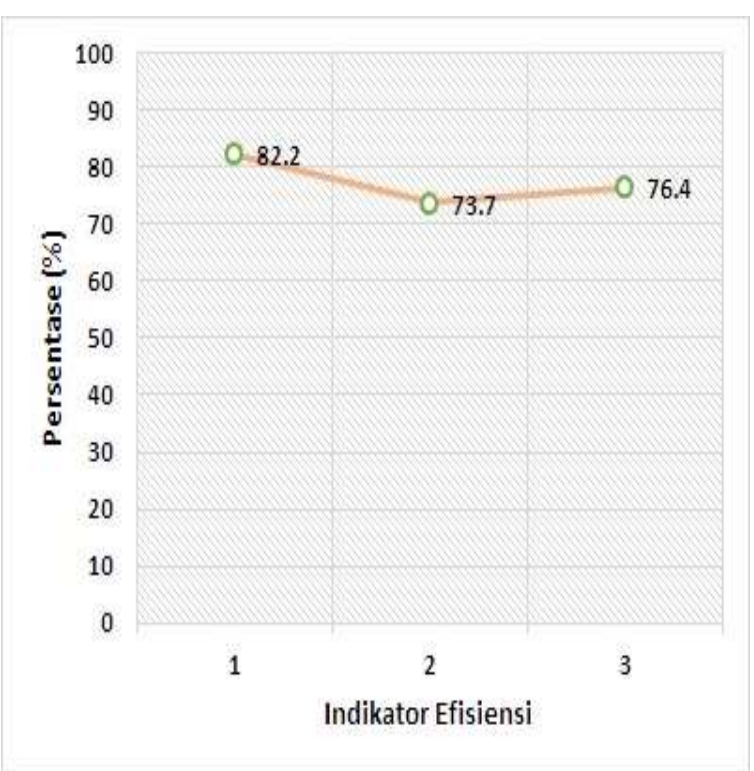

Gambar10. Indikator Efisiensi Penggunaan Bahan Ajar

Gambar 10 mengungkap hasil penilaian mahasiswa terhadap indikator efisiensi penggunaan bahan ajar dapat dijabarkan bahwa penggunaaan bahan ajar sudah dapat melatih kecermatan mahasiswa dalam menyelesaikan persoalan statistika. Penilaian terhadap butir ini mencapai nilai 82,2. Bahan ajar berupa bahan ajar yang sudah dikembangkan dapat digunakan untuk melatih kemandirian mahasiswa untuk belajar, ini juga didukung dengan adanya tersedia tugas terstruktur pada bahan ajar, penilaian terhadap butir ini mencapai nilai 76,4. Penggunaan bahan ajar ini juga sudah dapat mengefisienkan waktu perkuliahan dengan baik sesuai perencanaan pada silabus. Penilaian terhadap butir ini juga mencapai nilai 73,7.

\section{Pembahasan}

Kepraktisan bahan ajar statistika pendidikan fisika menggunakan model cooperative problem solving berada pada kriteria sangat praktis menurut dosen pengampu mata kuliah. Nilai ini diperoleh dari beberapa indikator kepraktisan. Indikator kemudahan penggunaan bahan ajar memiliki persentase terendah. Sedangkan, indikator daya tarik bahan ajar dengan memiliki persentase tertinggi.

Bahan ajar statistika pendidikan fisika menggunakan model cooperative problem solving berada pada kriteria praktis berdasarkan respon mahasiswa. Aspek daya tarik bahan ajarmemiliki persentase terendah. Sedangkan 
aspek efisiensi penggunaan bahan ajar pada proses perkuliahan memperoleh persentase tertinggi. Hal ini menunjukkan bahwa bahan ajar bermuatan cooperative problem solving tidak hanya dapat digunakan dalam group tetapi juga dapat digunakan secara mandiri oleh mahasiswa. Hal ini didukung dengan pendapat Heller (2010: 95) bahwa model cooperative problem solving dalam pelaksanaannya tidak hanya melatih bekerja dalam kelompok.

Bahan ajar statistika pendidikan fisika bermuatan model cooperative problem solving telah memberi manfaat bagi dosen dan mahasiswa. Manfaat itu terlihat dari kelebihan bahan ajar itu sendiri. Menurut dosen yang telah menggunakannya, bahan ajar yang telah dikembangkan dapat membuat waktu perkuliahan menjadi efektif dan materi yang padat dapat disajikan secara ringkas dan mendalam. Penggunaan bahan ajar dalam pembelajaran dan perkuliahan telah mampu membuat waktu pembelajaran dan perkuliahan lebih efisien (Andromeda, dkk: 2018; Yerimadesi, dkk, 2018; Sari, dkk, 2018).

Manfaat yang dirasakan oleh mahasiswa setelah menggunakan bahan ajar. Pertama, bahan ajar dapat membantu menyelesaikan permasalahan secara teratur. Kedua, bahan ajar telah merinci materi perkuliahansecara ringkas. Ketiga, bahan ajar dapat digunakan secara mandiri. Keempat, bahan ajar memberi kemudahan bagi mahasiswa untuk mengaitkan permasalahan pendidikan fisika dengan statistik yang digunakan. Hal ini didukung oleh pendapat Heiman (2011: 1) bahwa agar mengerti bidang studi yang dipilih maka harus menguasai statistik terutama bidang psikologi dan ilmu pendidikan karena berguna pada setiap harinya.

\section{KESIMPULAN}

Berdasarkan hasil penelitian dan pembahasan yang telah dilakukan, diperoleh kesimpulan bahwabahan ajar statistika pendidikan fisika bermuatan model cooperative problem solving telah praktis digunakan di dalam perkuliahan semester Juli-Desember 2018.

\section{DAFTAR PUSTAKA}

Andromeda, A., Ellizar, E., Iryani, I., Bayharti, B., \& Yulmasari, Y. (2018). Validitas dan Praktikalitas Modul Laju Reaksi Terintegrasi Eksperimen dan
Keterampilan Proses Sains untuk Pembelajaran Kimia di SMA. JURNAL EKSAKTA PENDIDIKAN (JEP), 2(2), 132-139. doi:10.24036/jep/vol2-iss2/250

Dewi, W., \& Afrizon, R. (2018). Analisis Kondisi Awal Perkuliahan Mahasiswa Pendidikan Fisika Dalam Rangka Mengembangkan Bahan Ajar Statistika Pendidikan Fisika Menggunakan Model Problem Solving. JURNAL EKSAKTA PENDIDIKAN (JEP), 2(1), 93-100. doi:10.24036/jep/vol2-iss1/140

Fauzan, A. 2002. Applying Realistic Mathematics Education (RME) in Teaching Geometry in Indonesian Primary Schools. Thesis. University of Twente, Enshcede.

Jan van den Akker, Brenda Bannan, Anthony E. Kelly. Nienke Nieveen, Tjeerd Plomp. 2013. Educational Design Research Part A: Introduction. Netherlands Institute for Curriculum Development (SLO), Enschede, the Netherlands.

Heiman, G.W. 2011. Basic Statistic for the Behavioral Sciences, Sixth Edition. Wadsworth, Cengage Learning Belmont USA.

Heller, K and Heller, P . 2010. Cooperative Problem Solving in Physics A User's Manual. U.S. University of Minnesota.

Khoe Yao Tung. 2016. Desain Instruksional Perbandingan Model dan Implementasinya. Jakarta: CV Andi Offset.

Tegeh, I M, dkk. 2014. Model Penelitian Pengembangan. Yogyakarta: Graha Ilmu

Riduwan. 2009. Belajar Mudah Penelitian Untuk Guru, Karyawan, dan Peneliti Pemula. Jakarta: Raja Grafindo Persada.

Sari, S.Y, Afrizon, R. 2018. The Practicality of Statistical Physics Handout Based on KKNI and the Constructivist Approach. IOP Conf. Ser.: Mater. Sci. Eng.335 012070. https://doi.org/10.1088/1757$\underline{\text { 899X/335/1/012070 }}$

Yerimadesi, Y., Bayharti, B., \& Oktavirayanti, R. (2018). Validitas Dan Praktikalitas Modul Reaksi Redoks dan Sel Elektrokimia Berbasis Guided Discovery Learning untuk SMA. JURNAL EKSAKTA PENDIDIKAN (JEP), 2(1), 1724. doi:10.24036/jep/vol2-iss1/143 